\title{
HUBUNGAN KONSTRUKSI SUMUR GALI DENGAN KUALITAS AIR SUMUR GALI DI DESA TAMBAHARJO KECAMATAN ADIMULYO KABUPATEN KEBUMEN TAHUN 2017
}

\author{
Yunita Setya Wardani ${ }^{*}$, Suparmin ${ }^{* *}$ ) \\ Jurusan Kesehatan Lingkungan, Politeknik Kesehatan Kemenkes Semarang, \\ Jl.Raya Baturaden KM 12 Purwokerto, Indonesia
}

\begin{abstract}
Abstrak
Sumur merupakan salah satu sarana untuk penyediaan air bersih bagi masyarakat yang memanfaatkan air tanah hasil resapan/ infiltrasi air hujan sehingga rawan terjadinya pencemaran Masyarakat Desa Tambaharjo menggunakan sumur gali sebagai sumber penyediaan air bersih untuk pemenuhan kebutuhan air bersih sehari - hari. Tujuan penelitian ini yaitu mengetahui apakah ada hubungan antara konsturksi sumur gali dan kualitas air sumur gali di Desa Tambaharjo Kecamatan Adimulyo, Kabupaten Kebumen tahun 2017.

Jenis penelitian ini yaitu penelitian analitik dengan metode cross sectional. Pegumpulan data dilakukan dengan observasi konstruksi sumur gali, wawancara, dan pemeriksaan parameter fisik, kimia dan mikrobiologi di Laboratorium Kesehatan Kebumen, dan Laboratorium Kesehatan Purbalingga.

Hasil penelitian menunjukkan dari 22 sumur gali terdapat 59\% yang konstruksi sumur galinya memenuhi syarat dan $41 \%$ konstruksi sumur galinya tidak memenuhi syarat,kualitas fisik air sumur $68 \%$ memenuhi syarat, $32 \%$ tidak memenuhi syarat, untuk kualitas mikrobiologi hasil pemeriksaan laboratorium menunjukkan dari 22 sampel 81\% sampel tidak memenuhi syarat dan 19\% memenuhi syarat, kualitas kimia detergen dari 22 sampel 100\% memenuhi syarat. Konstruksi sumur yang memenuhi syarat $59 \%$ dan yang tidak memenuhi syarat $41 \%$. Analisis statistikdilakukan dengan uji chi square diperoleh nilai $\mathrm{p}$ value kualitas fisik dan mikrobiologi $=0,421,0,125$ dan kualitas kimia diperoleh hasil $100 \%$ memenuhi syarat.

Simpulan yang diperoleh dari penelitian ini yaitu tidak ada hubungan antara konstruksi sumur gali dengan kualitas fisik, kimia dan mkirobiologi air sumur gali di desa Tambaharjo Kecamatan Adimulyo Kabupaten Kebumen.Saran yang diberikan antara lain melakukan perbaikan konstruksi sumur gali yang tidak memenuhi syarat, serta perlu menjaga dan merawat konstruksi sumur gali yang dalam keadaan baik, melakukan penyuluhan mengenai konstruksi sumur gali dan sanitasi lingkungan pada sarana air bersih.
\end{abstract}

Daftar bacaan : $32(1990-2017)$

Kata Kunci $\quad$ : kualitas air, konstruksi sumur gali, Kesehatan Lingkungan

\begin{abstract}
Dug well is one of clean source water for the community that utilizes soil water from the infiltration of rain water so that well was vulnerable to pollution. Tambaharjo Sub-district society use well water for daily clean water needs. The research objective was investigating the correlation between well construction and well water quality in Tambaharjo sub-ditrict Adimulyo District Kebumen regency year of 2017.

The research method used was analytical research with cross sectional design. The data were collected through well construction observation, interview, and examination of physical, chemical and microbiological parameter at Kebumen Health Laboratory and Purbalingga Health Laboratory.

The research result shows that from 22 wells there are 59\% that the construction qualify the requirements and $41 \%$ did not qualified, $68 \%$ of well water physical was qualified, 32\% was not qualified, $81 \%$ qualified the microbiological requirement and $19 \%$ was not qualified, $100 \%$ qualifies chemical detergent qualities eligible. The statistical analysis using chi square test obtained $\mathrm{p}$ value of physical and microbiological quality $=0.421$, and 0.12 , while detergent chemical quality statistical test cannot be done because $100 \%$ sample qualified requirement

The conclusion was; there was no correlation between well construction with physical, chemical and microbiological of dug well water quality in Tambaharjo Sub-District, Adimulyo District Kebumen Regency. The proposed suggestion was; repairing well construction that didn't qualify the requirement, and wells construction maintenance, counseling about wells construction and environmental sanitation at water facilities.
\end{abstract}

Keyword

: water quality, Well construction environmenthal health 


\section{Pendahuluan}

Menurut Peraturan Menteri Kesehatan (PERMENKES) Nomor 416 tahun 1990, yang dimaksud dengan air bersih adalah air yang digunakan untuk keperluan sehari - hari yang kualitasnya memenuhi syarat kesehatan dan dapat diminum apabila telah dimasak.

Sumur merupakan salah satu sarana untuk penyediaan air bersih bagi masyarakat yang memanfaatkan air tanah hasil resapan/ infiltrasi air hujan sehingga rawan terjadinya pencemaran. Oleh karena itu perlu dilakukan pengawasan terhadap kualitas air sumur baik kualitas fisik, kimia, maupun mikrobiologinya. Selain itu konsturksi sumur gali juga perlu di perhatikan, sumur yang terletak di dekat sumber pembuangan tinja, industrii kecil, saluran pembuangan air limbah dan lain lain apabila konstruksinya tidak baik kemungkinan besar akan terjadi pencemaran pada air oleh zat - zat yang berasal dari sumber pencemar tersebut. Sumur merupakan sumber utama persediaan air bersih bagi masyarakat yang tinggal di daerah pedesaan maupun perkotaan di Indonesia. Biasanya sumur yang ada di Indonesia adalah sumur gali. Sumur gali merupakan salah satu sumber air yang berasal dari air tanah dan mudah sekali terkontaminasi (Budiman Candra, 2007,h.45)

Persyaratan kualitas air bersih menurut Permenkes RI Nomor 416/Menkes/Per/IX/1990 tentan Persyaratan Kualitas Air untuk parameter fisik bau, rasa, dan warna standar maksimumnya tidak berbau, tidak berasa dan tidak berwrna. Kekeruhan standar maksimal yang diperbolehkan 5 NTU, standar maksimal untuk jumlah zat padat terlarut (TDS) minimal $1000 \mathrm{mg} / \mathrm{L}$. Desa Tambaharjo Kecamatan Adimulyo Kabupaten Kebumen merupakan suatu daerah dengan jumlah penduduk sebanyak 1938 dengan jumlah Kepala Keluarga (KK) sebanyak 472. Desa ini memiliki luas wilayah 217,84 Ha. Untuk pemenuhan kebutuhan air bersih penduduk Desa Tambaharjo Kecamatan Adimulyo Kabupaten Kebumen menggunakan sumur gali sebagai sumbernya, terdapat 419 sumur gali dimana jumlah sumur gali di Desa Tambaharjo Kecamatan Adimulyo Kabupaten Kebumen ini merupakan jumlah tertinggi yaitu sebanyak 88\% di Kecamatan Adimulyo. Setelah dilakukan survey pendahuluan pada 75 sumur gali, sekitar $\pm 80 \%$ sumur gali air yang keluar asin, selanjutnya sebanyak $\pm 5 \%$ air sumurnya berwarna kuning, $\pm 3 \%$ airnya keruh bila musim kemarau dan sisanya sebanyak $\pm 12 \%$ dari jumlah sumur yang ada memiliki kualitas air sumur yang cukup baik, sehingga mulai tahun 2014 penduduk Desa Tambaharjo Kecamatan Adimulyo Kabupaten Kebumen mengambil air dari sumur yang memiliki kualitas air yang cukup baik dan terdapat beberapa penduduk yang beralih menggunakan PDAM sebagai sumber air bersihnya.
Berdasarkan survey pendahuluan pada 75 sumur gali yang dilakukan di Desa Tambaharjo, penulis melihat secara fisik kondisi konstruksi sumur gali masih cukup baik, terdapat sekitar 30 (40\%) sumur gali yang tidak memenuhi syarat dan sebanyak $45(60 \%)$ sisanya memenuhi persyaratan sanitasi, salah satu diantaranya yaitu masih banyak sumur gali yang tidak berpenutup dan lantai sumur tidak kedap air atau masih tanah, dan jarak sumur gali dari sumber pencemar kurang dari 10m.

Penelitian ini bertujuan untuk mengetahui apakah ada hubungan antara konstruksi sumur gali dengan kualitas fisi, kimia (detergen) dan mikrobiolohi (bakteri Colliform) di Desa Tambaharjo Kecamatan Adimulyo Kabupaten Kebumen.

\section{Bahan dan Metode}

Jenis Penelitian ini merupakan penelitian analitik dengan metodeCross Sectional, yaitu peneliti melakukan observasi terhadap konstruksi sumur gali meliputi : dinding sumur, bibir sumur, lantai sumur dan juga SPAL yang dapat mempengaruhi kualitas air pada sumur gali, selanjutnya dilakukan analisis laboratorium pada sampel air yang di peroleh di lokasi penelitian.

Variabel bebas yaitu variabel yang berpengaruh atau menyebabkan berubahnya nilai dari variabel terikat dan merupakan variabel pengaruh yang paling utama dalam penelitian. Variabel bebas dari penelitian ini adalah konstruksi sumur gali. Variabel terikat yaitu variabel yang diduga nilainya akan berubah karena adanya pengaruh variabel bebas. Variabel terikat dalam penelitian ini adalah kualitas air sumur gali meliputi kualitas fisik dan mkirobiologi di Desa Tambaharjo Kecamatan Adimulyo Kabupaten Kebumen.

Populasi yang digunakan dalam penelitian ini adalah seluruh sumur gali yang berada di Desa Tambaharjo Kecamatan Adimulyo Kabupaten Kebumen dengan jumlah populasi keseluruhan sebanyak 419 sumur gali. Sampel dalam penelitian ini adalah sumur gali yang memenuhi kriteria inklusi berikut : a. Terdapat konstruksi sumur pada sumur gali, b. Sumur gali yang memiliki jarak > $10 \mathrm{~m}$ dari sumber pencemar, c Daerah sekitar sumur atau lantai sumur digunakan untuk aktifitas mencuci. Perhitungan besar sampel menggunakan rumus uji korelasi singgel. Dari hasil perhituga diperoleh sebanyak 22 sampel.

Instrumen Penelitian yang digunakan dalam penelitian ini yaitu checklist kontruksi sumur gali, kuisioner sumur gali dan dokumen.Checklist digunakan untuk menilai konstruksi sumur gali komponen sumur gali yang dinilai meliputi dinding sumur, lantai usmur, bibir sumur, saluran pembuangan air limbah (SPAL), jarak sumur gali dengan sumber pencemar dan sarana pengambilan air sumur.Kuisisoner digunakan untuk menilai jarak sumur gali dengan sumber pencemar.

Teknik pengambilan data dilakukan dengan observasi, pengukuran, dan pemeriksaan labotarorium . 
Observasi dilakukan pada konstruksi sumur gali dengan bantuan checklist, pengukuran dilakukan pada kualitas fisik air sumur gali.Pemeriksaan laboratorium dalam penelitian ini untuk memeperoleh datakandungan bakteri colliform dan kandungan detergen pada air sumur.Pemeriksaan kandungan bakteri colliform pada air sumur dilakukan dengan metode MPN sedangkan pemeiksaan kandungan detergen pada air menggunakan metode spektofotmetri.

Untuk memperoleh suatu kesimpulan masalah yang diteliti, maka analisis data merupakan suatu langkah penting dalam penelitian. Data yang telah terkumpul akan diolah dan dianalisis. Proses pengolahan data meliputi editing, koding, entri, dan tabulating. Editing adalah kegiatan untuk memeriksa kelengkapan data yang diperoleh melalui observasi atau pengamatan.Koding adalah kegiatan untuk memberikan kode pada semua variabel untuk mempermudah pengolahan data.Entri adalah kegiatan memasukkan data ke dalam program komputer.Tabulating adalah kegiatan untuk mengelompokkan data sesuai dengan variabel yang akan diteliti guna memudahkan untuk disusun dan ditata untuk disajikan.

Setelah semua data terkumpul maka langkah selanjutnya adalah menganalisis data. Analisis data dalam penelitian ini menggunakan teknik sebagai berikut:
Analisis univariat dilakukan terhadap tiap variabel dari hasil penelitian. Adapun va-riabel yang digambarkan yaitu konstruksi sumur gali yang meliputi : tinggi dinding sumur, lantai sumur, bibir sumur, letak timba, jarak jamban, jarak SPAL, tutup sumur, jarak kandang ternak, jarak tempat sampah, Kualitas fisik air, kualitas kimia kandungan detergen air, dan kualitas mikrobiologi kandungan bakteri colliform pada air.

Analisis bivariat dilakukan untuk menge-tahui faktor-faktor yang berhubungan dengan kualitas air sumur gali dengan menggunakan chi square, Kemudian akan dilakukan pembuktian hubungan variabel bebas dengan variabel terikat dengan ketentuan:

Jika $\mathrm{P}<\alpha=0,05$, maka hipotesis nol (Ho) ditolak dan hipotesis alternatif (Ha) di- terima artinya ada hubungan.

Jika $\mathrm{P}>\alpha=0,05$, maka hipotesis nol (Ho) diterima dan hipotesis alternatif (Ha) ditolak artinya tidak ada hubungan.

\section{Hasil dan Pembahasan}

Data sarana air bersih Desa Tambaharjo berdasarkan profil desa tahun 2017 sarana air bersih yang digunakan oleh penduduk Desa Tambaharjo mayorits menggunakan sumur gali sebanyak 419 buah dan terdapat 2 buah penampungan air hujan.

Tabel 1. Distribusi Aspek Konstruksi Sumur Gali

\begin{tabular}{|c|c|c|c|c|c|c|c|}
\hline & \multirow[t]{2}{*}{ Aspek - aspek konstruksi sumur gali } & \multicolumn{2}{|c|}{$\begin{array}{l}\text { Memenuhi syarat } \\
\text { (MS) }\end{array}$} & \multicolumn{2}{|c|}{$\begin{array}{l}\text { Tidak memenuhi } \\
\text { Syarat } \\
\text { (TMS) }\end{array}$} & \multicolumn{2}{|c|}{ Total } \\
\hline & & $\mathbf{n}$ & $\%$ & $\mathbf{n}$ & $\%$ & $\mathbf{n}$ & $\%$ \\
\hline \multirow[t]{3}{*}{ A. } & Dinding Sumur & & & & & & \\
\hline & $\begin{array}{l}\text { 1. Dari permukaan tanah kedalaman } 3 \mathrm{~m} \\
\text { dibuat tembok, kedap air (terbuat dari } \\
\text { semen) }\end{array}$ & 22 & $100 \%$ & 0 & $0 \%$ & 22 & $100 \%$ \\
\hline & $\begin{array}{l}\text { 2. Kedalaman } 1,5 \text { m berikutnya dibuat dari } \\
\text { bata, tidak kedap air }\end{array}$ & 22 & $100 \%$ & 0 & $0 \%$ & 22 & $100 \%$ \\
\hline \multirow[t]{2}{*}{ B. } & $\begin{array}{l}\text { Bibir Sumur } \\
\text { 3. Ditembok kedap air (disemen) }\end{array}$ & 22 & $100 \%$ & 0 & $0 \%$ & 22 & $100 \%$ \\
\hline & 4. Tembok setinggi minimal $70 \mathrm{~cm}$ & 22 & $100 \%$ & 0 & $0 \%$ & 22 & $100 \%$ \\
\hline \multirow[t]{5}{*}{ C. } & Lantai Sumur & & & & & & \\
\hline & $\begin{array}{l}\text { 5. Dibuat dari mester yang kedap air } \\
\text { (disemen) }\end{array}$ & 22 & $100 \%$ & 0 & $0 \%$ & 22 & $100 \%$ \\
\hline & $\begin{array}{l}\text { 6. Lebar lantai sumur gali } \pm 1,5 \mathrm{~m} \text { dari } \\
\text { dinding sumur }\end{array}$ & 19 & $86 \%$ & 3 & $14 \%$ & 22 & $100 \%$ \\
\hline & $\begin{array}{l}\text { 7. Lantai dibuat agak miring ke arah } \\
\text { saluran pembuangan (tidak terdapat } \\
\text { genangan) }\end{array}$ & 17 & $77 \%$ & 5 & $23 \%$ & 22 & $100 \%$ \\
\hline & 8. Lantai dibuat mengitari sumur gali & 22 & $100 \%$ & 0 & $0 \%$ & 22 & $100 \%$ \\
\hline
\end{tabular}




\begin{tabular}{|c|c|c|c|c|c|c|c|}
\hline & \multirow[t]{2}{*}{ Aspek - aspek konstruksi sumur gali } & \multicolumn{2}{|c|}{$\begin{array}{l}\text { Memenuhi syarat } \\
\text { (MS) }\end{array}$} & \multicolumn{2}{|c|}{$\begin{array}{c}\text { Tidak memenuhi } \\
\text { Syarat } \\
\text { (TMS) }\end{array}$} & \multicolumn{2}{|c|}{ Total } \\
\hline & & $\mathbf{n}$ & $\%$ & $\mathbf{n}$ & $\%$ & $\mathbf{n}$ & $\%$ \\
\hline & $\begin{array}{l}\text { 9. Lantai sumur gali mempunyai tinggi } 10 \\
-20 \mathrm{~cm} \text { dari permukaan tanah }\end{array}$ & 18 & $82 \%$ & 4 & $18 \%$ & 22 & $100 \%$ \\
\hline \multirow[t]{3}{*}{ D. } & Saluran Pembuangan Air Limbah (SPAL) & & & & & & \\
\hline & $\begin{array}{l}\text { 10. Panjang saluran pembuangan air limbah } \\
\text { minimal } 10 \mathrm{~m}\end{array}$ & 13 & $59 \%$ & 9 & $41 \%$ & 22 & $100 \%$ \\
\hline & 11. Berfungsi dengan baik & 18 & $82 \%$ & 4 & $18 \%$ & 22 & $100 \%$ \\
\hline \multirow[t]{5}{*}{ E. } & Sumber Pencemaran Lainnya & & & & & & \\
\hline & $\begin{array}{l}\text { 12. Sumur gali berjarak lebih dari } 10 \mathrm{~m} \\
\text { dari kandang ternak / kotoran ternak, }\end{array}$ & 22 & $100 \%$ & 0 & $0 \%$ & 22 & $100 \%$ \\
\hline & $\begin{array}{l}\text { 13. Sumur gali berjarak lebih dari } 10 \mathrm{~m} \\
\text { dari sungai. }\end{array}$ & 22 & $100 \%$ & 0 & $0 \%$ & 22 & $100 \%$ \\
\hline & $\begin{array}{l}\text { 14. Sumur gali berjarak lebih dari } 10 \mathrm{~m} \\
\text { septictank. }\end{array}$ & 22 & $100 \%$ & 0 & $0 \%$ & 22 & $100 \%$ \\
\hline & $\begin{array}{l}\text { 15. Sumur gali berjarak lebih dari } 10 \mathrm{~m} \\
\text { lubang galian sampah. }\end{array}$ & 22 & $100 \%$ & 0 & $0 \%$ & 22 & $100 \%$ \\
\hline \multirow[t]{2}{*}{ F. } & Fasilitas / Alat Bantu & & & & & & \\
\hline & 16. Terdapat ember dan atau tali timba & 18 & $82 \%$ & 4 & $18 \%$ & 22 & $100 \%$ \\
\hline
\end{tabular}

Berdasarkan hasil yang diperoleh gambaran konstruksi sumur yang ada di Desa Tambaharjo Kecamatan Adimulyo Kabupaten Kebumen yaitu dinding sumur minimal sedalam $3 \mathrm{~m}$ dari permukaan lantai atau tanah dibuat dari tembok atau bahan kedap air teridentifikasi $100 \%$ memenuhi syarat; untuk kedalaman 1,5 berikutnya dibuat dari bata, tidak kedap air teridentifikasii $100 \%$ memenuhi syarat. Dinding sumur dibuat dari tembok semen kedap air teridentifikasi 100\% memenuhi syarat, bibir sumur di tembok lebih dari $70 \mathrm{~cm}$ teridentifikasi 100\% memenuhi syarat. Untuk lantai sumur dibuat dari mester yang kedap air atau terbuat dari semen teridentifikasi $100 \%$ memenuhi syarat; lebar lantai sumur gali $\pm 1,5 \mathrm{~m}$ dari dinding sumur teridentifikasi $6 \%$ memenuhi syarat dan $14 \%$ tidak memenuhi syarat; lantai sumur dibuat agak miring ke rah saluran pembuangan teridentifikasi $77 \%$ memenuhi syarat dan $23 \%$ tidak memenuhi syarat; lantai sumur dibuat mengitari sumur gali teridentifikasi 100\% memenuhi syarat; lantai sumur gali mempuanyai tinggi $10-20 \mathrm{~cm}$ dari permukaan tanah teridentifikasi $82 \%$ memenuhi syarat dan $28 \%$ tidak memenuhi syarat.

Saluran pembuangan air limbah panjang saluran lebih dari $10 \mathrm{~m}$ teridentifikasi 59\% memenuhi syarat dan 41\% tidak memenuhi syarat; saluran pembuangan air limbah berfungsi dengan baik teridentifikasi $82 \%$ memenuhi syarat dan 18\% tidak memenuhi syarat. Untuk sumber pencemaran lainnya, sumur gali berjarak lebih dari $10 \mathrm{~m}$ dari kandang ternak terientifikai 100\% memenuhi syarat; sumur gali berjarak lebih dari $10 \mathrm{~m}$ dari sungai teridentifikasi $100 \%$ memenuhi syarat; sumur gali berjarak lebih dari $10 \mathrm{~m}$ dari septictank teridentifikasi 100\% memenuhi syarat; sumur gali berjarak lebih dari $10 \mathrm{~m}$ dari lubang galian sampah teridentifikasi $100 \%$ memenuhi syarat. Untuk fasilitas atau alat bantu pada sumur gali terdapat ember dan atau tali timba teridentifikasi 82\% memenuh syarat dan $18 \%$ tidak memenuhi syarat.

Menurut Joeharno (2006) konstruksi sumur gali yang tidak memenuhi syarat disebabkan oleh ; kurangnya pengetahuan pemilik sumur tersebut terutama pengetahuan mengenai persyaratan konstruksi sumur gali yang sesuai standard dan bahaya dapat di timbulkan apabila konstruksi sumur gali tidak memenuhi syarat. Aspek lain yang dapat memepengaruhi sumur gali tidak memenuhi syarat yaitu keadaan perekonomian masyarakat dimana untuk membuat sumur gali dengan kontruksi yang memenuhi syarat akan memerlukan dana yang lebih besar. Selain itu terdapat aspek lain yaitu kurangnya lahan yang di miliki sehingga lokasi sumur gali dengan saluran pembuangan atau SPAL jaraknya tidak memenuhi syarat.

a. Kualitas Fisik

Tabel 2. Kualitas Fisik Air sumur Gali

\begin{tabular}{lllll}
\hline No & Kategori & MS & TMS & Jumlah \\
\hline 1 & Bau & 19 & 3 & 22 \\
\hline 2 & Rasa & 7 & 15 & 22 \\
\hline 3 & Warna & 20 & 2 & 22 \\
\hline
\end{tabular}


Berdasarkan tabel 2 pemeriksaan kulitas fisik air dilakukan dengan cara organoleptik oleh peneliti dan diperoleh hasil bahwa mayoritas air sumur gali di Desa Tambaharjo berasa yaitu sebanyak 15 sumur gali dan 7 sumur gali dikatakan memenuhi syarat. Berdasarkan observasi terdapat 13 (59,\%) sumur gali yang memenuhi syarat dan 9 (41\%) sumur gali tidak memenuhi syarat.

Rasa pada air dapat ditimbulkan karena adanya perbedaan kedalaman sumur, dan perbedaan jenis tanah. Menurut Margareta (2012) warna air dapat ditimbulkan oleh adanya organisme, bahan - bahan tersuspensi yang berwarna oleh ekstrak senyawa senyawa organik serta tumbuh - tumbuhan. Sedangkan bau dapat dihasilkan oleh adanya organisme dalam air seprti alga serta adanya gas seperti $\mathrm{H}_{2} \mathrm{~S}$ yang terbentuk dalam kondisi anaerobik dan adanya senyawa senyawa organik tertentu.

\section{b. Kualitas Mikrobiologi}

Tabel 3. Kualitas Mikrobiologi

\begin{tabular}{llcc}
\hline No & \multicolumn{1}{c}{ Kategori } & Jumlah & $\%$ \\
\hline 1. & $50 / 100 \mathrm{ml}$ (MS) & 5 & $23 \%$ \\
2. & $>50 / 100 \mathrm{ml}$ (TMS) & 17 & $77 \%$ \\
\hline & Jumlah & 22 & $100 \%$ \\
\hline
\end{tabular}

Berdasarkan tabel 3 pemeriksaaan kualitas bakteriologis yang telah dilakukan oleh Laboratorium Kesehatan Daerah Kabupaten Kebumen tahun 2017 untuk Desa Tambaharjo Kecamatan Adimulyo Kabupaten Kebumen, yaitu dengan jumlah sampel sumur gali sebanyak 22 sampel sumur gali. Hasil pemeriksaan yang telah dilakukan pada 22 sampel diperoleh hasil kualitas bakteriologis yang memenuhi syarat sebanyak 5 sampel dan sampel yang memenuhi syarat sebanyak 17 sampel sesuai Permenkes RI Nomor : 416/Menkes/Per/IX/1990 yaitu jumlah maksimum total colliform yang diperbolehkan pada air bersih non perpipaan 50/100 ml.

Menurut Depkes RI Dirjen PP \& PL Direkorat Penyehatan Lingkungan (2007) untuk mencegah terjadinya pencemaran bakteri colliform terhadap air sumur maka diperlukan kosntruksi sumur yang memenuhi persyaratan sanitasi. Persyaratan kesehatan sarana sanitasi air bersih sumur gali diantaranya yaitu lokasi sumur gali, lantai sumur gali, saluran pembuangan limbah, bibir sumur gali, dinding sumur gali dan peletakan timba atau tali timba.

\section{c. Kualitas Kimia}

Tabel 4. Kualitas kimia

\begin{tabular}{llcc}
\hline No & \multicolumn{1}{c}{ Kategori } & Jumlah & $\%$ \\
\hline 1. & $<0,5 \mathrm{mg} / \mathrm{L}$ (MS) & 22 & $100 \%$ \\
2. & $>0,5 \mathrm{mg} / \mathrm{L}$ (TMS) & 0 & $0 \%$ \\
\hline \multicolumn{2}{c}{ Jumlah } & 22 & $100 \%$ \\
\hline
\end{tabular}

Berdasarkan tabel 4pemeriksaan kualitas kimia Detergen yang telah dilakukan oleh Laboratorium Kesehatan Kabupaten Purbalingga tahun 2017 untuk Desa Tambaharjo Kecamatan Adimulyo Kabupaten Kebumen, dengan jumlah sampel sumur gali sebanyak 22 sumur gali. Dari pemeriksaaan kimia detergen yang telah dilakukan pada 22 sampel air sumur gali, diperoleh hasil sebanyak 22 sampel memenuhi syarat sesuai Permenkes RI Nomor : 416/Menkes/Per/IX/1990 untuk jumlah maksimum kadar detergen yang diperbolehkan pada air bersih non perpipaan : 0,5mg/L.

Menurut Peni Adi (2015) kandungan detergen pada air sumur dapat terjadi apabila air sumur terkontaminasi oleh limbah domestik seperti sabun cuci karena rembesan dari lantai sumur, atau limbah industri yang pembuangannya tidak memenuhi persyaratan sehingga dapat massuk ke sumber air.

d. Hubungan Konstruksi Sumur Gali dengan Kualitas Fisik Air Sumur Gali

Tabel 5. Hubungan kosntruksi sumur gali dengan kualitas fisik air sumur gali

\begin{tabular}{ccccccc}
\hline \multirow{2}{*}{$\begin{array}{c}\text { Konstruksi } \\
\text { sumur gali }\end{array}$} & \multicolumn{4}{c}{ Kualitas fisik air } & \multicolumn{2}{c}{ Total } \\
\cline { 2 - 6 } & \multicolumn{2}{c}{ MS } & \multicolumn{2}{c}{ TMS } & & \\
\cline { 2 - 6 } & $\mathrm{N}$ & $\%$ & $\mathrm{n}$ & $\%$ & $\mathrm{n}$ & $\%$ \\
\hline MS & 5 & $38,5 \%$ & 8 & $61,5 \%$ & 13 & $100 \%$ \\
\hline TMS & 2 & $22,2 \%$ & 7 & $77,8 \%$ & 9 & $100 \%$ \\
\hline Total & 7 & $31,8 \%$ & 15 & $68,2 \%$ & 22 & $100 \%$ \\
\hline
\end{tabular}

Hasil uji statistik chi square dengan nilai $\alpha=5 \%$ $(0,05)$ diperoleh nilai $\mathrm{p}$ value $=0,421$ (nilai $\mathrm{p}$ value $>$ $0,05)$ artinya tidak ada hubungan antara konstruksi sumur gali dengan kualits fisik sumur gali di Desa Tambaharjo Kecamatan Adimulyo Kabupaten Kebumen tahun 2017.

Hasil penelitian ini sama dengan hasil penelitian yang dilakukan oleh Joeharno (2006) yang menyatakan bahwa kualitas fisik air sumur gali tidak dipengaruhi oleh konstruksi sumur gali, dimana hasil pemeriksaan diperoleh bahwa konstruksi sumur gali yang tidak memenuhi syarat memiliki kualitas fisik air sumur gali yakni tidak berbau, tidak berasa, tidak berwarna, tidak keruh, dan memeiliki suhu yang optimal lebih dominan pada konstruksi sumur gali yang tidak memenuhi syarat.

Konstruksi sumur gali yang kurang baik dapat berpotensi besar menimbulkan pencemaran pada air sumur sehingga menurunkan kualitas fisik air sumur gali. Menurut Anggela (2012) dinding sumur gali yang tidak kedap air atau tidak memenuhi syarat dapat mengakibatkan terjadinya rembesan air melewati pori pori tanah sehingga air sumur gali dapat tercemar dan kualitas fisik air sumur gali mengalami penurunan. Selain itu dari aspek lain seperti bibir sumur, penutup sumur, lantai sumur, saluran pembuangan air limbah 
dapat memepengaruhi kualitas fisik air sumur apabila konstruksi sumur gali tidak memenuhi syarat.

e. Hubungan konstruksi sumur gali dengan kualitas mikrobiologi air

Tabel 6. Hubungan konstruksi sumur gali dengan

\begin{tabular}{|c|c|c|c|c|c|c|}
\hline \multirow{4}{*}{$\begin{array}{c}\text { Konstruk } \\
\text { si sumur } \\
\text { gali }\end{array}$} & \multirow{2}{*}{\multicolumn{4}{|c|}{$\begin{array}{l}\text { Kualitas mikrobiologi } \\
\text { air }\end{array}$}} & & \\
\hline & & & & & \multirow{2}{*}{\multicolumn{2}{|c|}{ Total }} \\
\hline & \multicolumn{2}{|c|}{ MS } & \multicolumn{2}{|c|}{ TMS } & & \\
\hline & $\mathrm{n}$ & $\%$ & $\mathrm{n}$ & $\%$ & $\mathrm{n}$ & $\%$ \\
\hline MS & 1 & $7,77 \%$ & 12 & $92,3 \%$ & 13 & $100 \%$ \\
\hline TMS & 3 & $33,3 \%$ & 6 & $66,7 \%$ & 9 & $100 \%$ \\
\hline Total & 4 & $18,2 \%$ & 18 & $81,8 \%$ & 22 & $100 \%$ \\
\hline
\end{tabular}

Hasil analisis chi square dengan nilai signifikan $\alpha=5 \%(0,05)$ menunjukan hasil niali $\mathrm{p}$ value $=0,421$ lebih besar dari $\alpha=0,05$ maka artinya tidak terdapat hubungan yang signifikan antara konstruksi sumur gali dengan kulatias mikrobiologi atau kandungan bakteri coliform

Hasil penelitian ini berbeda dengan penelitian yang dilakukan oleh Rahayu Sri ( 2010 ) yang menyatakan bahwa kualtias mikrobilogi air sumur di Kelurahan Citrodiwangsan Kabupaten Lumajang dipengaruhi oleh konstruksi sumur gali. Perbedaan hasil penelitan ini dengan penelitian yang dilakukan oleh Rahayu Sri (2010) yaitu berdasarkan observasi diketahui bahwa hampir seluruh aspek konstruksi sumur gali tidak memenuhi syarat, sebagai contoh pada saluran pembuangan air limbah sebanyak 67,4\% sumur gali saluran pembuangannya $>10 \mathrm{~m}$ atau tidak memenuhi syarat dan hasil pemeriksaan mikrobiologi di laboratorium medis dan lingkungan Kabupaten Lumajang menunjukkan hamper seluruh air sumur gali (91,3\%) tergolong kategori tidak memenuhi syarat bedasarkan Permenkes RI Nomor 416 Tahun 1990 tentan Persyaratan Kualitas Air.

Menurut Depkes RI Dirjen PP \& PL Direktorat Penyehatan Lingkungan (2007) untuk mencegah terjadinya pencemaran bakteri Coliform terhadap air sumur gali maka perlu konstruksi sumur yang memenuhi persyaratan sanitasi. Persyaratan kesehatan sarana sanitasi air bersih sumur gali yaitu diantaranya pada lokasi sumur gali tidak kdekat dengan sumber pencemar (jamban, kandang ternak, TPS, dll). Pada lantai sumur harus kedap air dengan lebar dan luas minimal $1 \mathrm{~m}$ dari tepi dinding/ bibir sumur, tidak retak / bocor \& mudah dibersihkan. Pada saluran pembuangan limbah (SPAL) harus kedap air, minimal panjang saluran lebih kurang $11 \mathrm{~m}$ dan tidak menimbulkan genangan, pada dinding sumur minimal sedalam $3 \mathrm{~m}$ dari permukaan lantai dibuat bahan kedap air dan kuat. Dan pada bibir sumur minimal $80 \mathrm{~cm}$ dari lantau, terbuat dari bahan yang kuat dan kedap air serta bibir sumur diberi penutup.

\section{f. Hubungan Konstruksi Sumur Gali Dengan Kualitas kimia air sumur}

Tabel 7. Hubungan Konstruksi Sumur Gali Dengan Kualitas Kimia Air sumur

\begin{tabular}{ccccccc} 
& \multicolumn{6}{c}{ Kualitas Kimia Air sumur } \\
\hline \multirow{2}{*}{$\begin{array}{c}\text { Konstruksi } \\
\text { sumur gali }\end{array}$} & \multicolumn{2}{c}{ Kualitas fisik air } & \multicolumn{2}{c}{ Total } \\
\cline { 2 - 5 } & \multicolumn{2}{c}{ MS } & \multicolumn{2}{c}{ TMS } & & \\
\cline { 2 - 5 } & $\mathrm{N}$ & $\%$ & $\mathrm{n}$ & $\%$ & $\mathrm{n}$ & $\%$ \\
\hline MS & 13 & 0 & 0 & 13 & $100 \%$ \\
\hline TMS & 9 & 0 & 0 & 9 & $100 \%$ \\
\hline Total & 22 & 0 & 0 & 22 & $100 \%$ \\
\hline
\end{tabular}

Berdasarkan hasil yang di peroleh menunjukkan bahwa semua sampel air sumur gali yang di periksa memenuhi syarat, sehingga tidak dapat dilakukan perhitungan menggunakan uji chi square.

Pada penelitian yang dilakukan oleh Peni Adi (2015) menyatakan bahwa tidak ada hubungan antara jarak pembuangan limbah cair dengan kandungan COD dan MBAS (sulfaktan) pada air sumu di Gang Cempaka dan Gang Nangka di wilayah Kampus UNNES Semarang. Jenis penelitian ini deskriptif dengan subyek penelitian sumur yang masih digunakan untuk kebutuhan sehari - hari di Gang Nangka dan Gang Cempaka. Hasil penelitian ini menunjukkan bahwa sampel limbah laundry memiliki kadar MBAS paling tinggi sebesar 32,50 mg/L dan COD sebesar 1.575 mg.L, pada 22 air sumur gali semuannya mengandung kadar COD yang melebihi baku mutu meneurut Peraturan Daerah Provinsi Jawa Tengah No 10 tahun 2004, kandungan sulfaktan dalam jumlah sedikit, $\mathrm{pH}$ dan kekeruham masih dalam batas normal, berdasarkan observasi terdapat 9 sumur di Gang Cempaka dan 2 pada Gang Nangka tidak memenuhi kriteria pembuatan sumur sehat.

Menurut Tjokrokusumo (1997) adanya kandungan MBAS atau detergen pada air sumur dapat terjadi karena rembesan yang terjadi akibat tidak adanya lantai sumur, retaknya lantai sumur, atau samluran pembuangan yang dekat dengan sumur gali. Sehingga limbah domestic atau industri kecil seperti laundry yang menghasilkan limbah cair berupa detergen dapat masuk ke badan air dan mencemari air tanah.

\section{Simpulan}

Berdasarkan hasil penelitian dan pembahasan dapat diperoleh disimpulan sebagai berikut :

Konstruksi sumur gali yang memenuhi syarat sebanyak 13 buah (58\%) dan yang tidak memenuhi syarat sebanyak 9 buah (41\%) , dimana konstruksi sumur gali yang paling banyak tidak memenuhi syarat terdapat pada aspek Saluran Pembuangan Air Limbah 
(SPAL) yang jaraknya $>10 \mathrm{~m}$ dari sumur gali yaitu sebayak $41 \%$

Berdasarkan pemeriksaan kualitas fisik air sumur gali secara organoleptik diperoleh hasil 15 sampel (69\%) air sumur gali memenuhi syarat dan 7 sampel (31\%) air sumur gali tidak memenuhi syarat. Dimana standar kualitas air bersih sesuai ketentuan Permenkes RI No. 416/Menkes/Per/IX/1990 bahwa standar kualitas fisik air bersih yaitu tidak berbau, tidak berasa dan tidak berwarna.

Berdasarkan analisis laboratorium untuk hasil pemeriksaan kualitas kimia atau kandungan detergen air sumur gali di Desa Tmabaharjo tahun 2017 diperoleh hasil sebanyak 22 sampel (100\%) memenuhi syarat. Dimana standar kualitas air bersih sesuai ketentuan Permenkes RI No. 41/Menkes/Per/IX/1990 bahwa standar minimum kandungan detergen pada air bersih yaitu $0,5 \mathrm{Mg} / \mathrm{L}$.

Berdasarkan hasil laboratorium untuk hasil pemeriksaan mikrobiologi yaitu kandungan bakteri colliform air sumur gali di Desa Tambaharjo yaitu sebanyak 17 sampel (81\%) air sumur tidak memenuhi syarat dan 5 sampel (19\%) sumur gali memenuhi syarat. Dimana standar kualitas air bersih sesuai ketentuai Permenkes RI No. 416/Menkes/Per/IX/1990 bahwa air yang merupakan bukan air perpipaan kandungan bakteri colifrom per $100 \mathrm{ml}$ air sampel kadar maksimum yang diperbolehkan 50 .

Hasil analisis data menujukan bahwa tidak ada hubungan yang signifikan antara konstruksi sumur gali dengan kulitas fisik, dan mikrobiologi air sumur gali di Desa Tambaharjo tahun 2017 dimana hasil uji chi square kualitas fisik nilai $\mathrm{p}$ value $=0,421$, kualitas mikrobiologi nilai $\mathrm{p}$ value $=0,125$ (nilai $\mathrm{p}$ value $>$ 0,05 ), untuk kualitas kimia semua sumur gali memenuhi syarat.

\section{Ucapan Terima Kasih:}

Penyelesaian penulisan karya tulis ilmiah ini penyusun banyak mendapatkan bantuan baik materil maupun moril dari berbagai pihak, untuk itu penyusun mengucapkan terima kasih kepada:Bapak Suparmi, SST.,M.Kes selaku pembimbing karya tulis ilmiah yang telah memberikan bimbingan dan saran yang membangun untuk peneliti.Keluarga tercinta, Bapak, Ibu serta Kakaku tersayang yang telah memberikan doa serta dukungan dalam proses pembuatan karya tulis ilmiah.Keluarga SARAS yang selalu memeberikan dukungan serta doa untuk kelancaran dalam pembuatan karya tulis ini .Sahabat tersayang yang selalu memberi motivasi dan semangat.Pihak Desa Tambaharjo beserta jajarannya yang membantu kelancaran pembuatan karya tulis ini .Penulis menyadari bahwa di dalam menyelesaikan karya tulis ilmiah ini masih jauh dari sempurna. Oleh karena itu, penulis mengharapkan kritik dan saran yang membangun untuk kesempurnaan karya tulis ilmiah ini pada waktu yang akan datang. Harapan penulis semoga karya tulis ilmiah ini dapat berguna dan bermanfaat bagi penulis maupun bagi pembaca pada umumnya.

\section{Daftar Pustaka:}

Anonim 2003.Laporan Praktik Penentuan Kadar Air. Jakarta: scribed.com

Arikunto, Suharsimi, 2006, Metode Penelitian, Yogyakarta : Bina Aksara

Aditya Puspitasari. 2016. Hubungan Sanitasi Sumur Gali Dan Kualitas Bakteriologis Dengan Prevalensi Diare Infeksi Desa Pengebatan Kecamatan Karanglewas Kabupaten banyumas Tahun 2016. Purwokerto: Kementrian Kesehatan RI Poltekkes Kemenkes Semarang Jurusan Kesehatan Lingkungan Purwokerto

Aditya Wibawa, dkk. 2017. Pengenalan Polusi Kebauan Berdasarkan Parameter Bau Dengan Sampel Limbah Di Lingkungan Sekitar. Bogor: Instritut Pertanian Bogor, Departemen Teknik Sipil

Anggela Suryani Katho, dkk. 2012. Gambaran Kondisis Fisik Sumur Gali Ditinjau Dari Aspek Kesehatan Lingkungan Dan Perilaku Pengguna Sumur Gali Di Keluarahan Sumompo Kecamatan Tuminting Kota Manado. Manado: Jurnal Kesehatan Masyarakat. Vol 1 No 1

Daryanto. 1995. Masalah Pencemaran. Bandung : Tarsito

Departemen Kesehatan RI, 1990, Peraturan Menteri Kesehatan RI No.416/Menkes/Per/IX/1990 tentang Persyarata Kualitas Air Bersih

Departemen Kesehatan RI, 2010, Peraturan Menteri Kesehatan RI Nomor 736 Tahun 2010 tentang Tata Laksana Kualias Air Minum

Departemen Kesehatan RI, 2007, Direktorat Jendral PP \& PL Direktorat Penyehatan Lingkungan 2007

Departemen Kesehatan RI. 1998. Direktorat Penyehatan Air. Dirjen PPM \& PLP

Eram Tunggul P, 2012. Pengelolaan Sumber Air Di Desa Jawesarai Kecamatan Limbangan 
Kabupaen Kendal. Semarang: Jurnal Kesehatan Masyarakat.KESMAS 8 (1) : 12 $-22$

Erwita, dkk. 2011. Pencemaran terhadap Organisme Perairan. Medan : Universitas Negeri Medan Fakultas Matematika dan Ilmu Pengetahuan Alam

Gufran H Kordi M dan Andi Baso Tancung.2007. Pengelolaan Kualitas Air Dalam Budidaya Perairan. Jakarta: PT RinekaCipta

Hardjojo.Basuki. 2008.Pengukuran dan Analisis Kualitas Air Cetakan 3. Jakarta: Universitas Terbuka

Hefni Efrendi, 2003. Telaah Kualitas Air Bagi Pengelolaan Sumber Daya dan Lingkungan Perairan. Yogyakarta: Penerbit Kanius

Herdian, Ahmad Ramadhani, 2015, Gambaran Kadar Detergen Pada Air Aliran Sungai Desa Mekar Kecamatan Martapura Timur Maret 2015, Karya Tulis Ilmiah, Banjarmasin: Kemeterian Kesehatan Republik Indonesia Politeknik Kesehatan Banjarmasin Jurusan Analis Kesehatan.

Herwin Sinabang, Fawanri, 2009, Studi Kualitas Mikrobiologi Air Sumur Gali di Kelurahan Larangan Kecamatan Larangan Kabupaten Brebes Tahun 2009, Karya Tulis Ilmiah, Purwokerto: Kementerian Kesehatan RI Politeknik Kesehatan Semarang Jurusan Kesehatan Lingkungan Purwokerto

Indah Entjang. 2000, Ilmu Kesehatan Masyarakat . Jakarta:Citra Adya Bakti

Joeharno.2006. Kualitas Air Berdasarkan Konstruksi Sumur Gali Di Wilayah Kerja Puskesmas Antang Kota Makassar Tahun 2006. Skripsi Makassar: Universitas Hasanuddin Makasar

Kartin Margaretha Widagdo dan Eko Hartini, 2012, Beberapa Faktor Yang Berhubungan Dengan Kualitas Fisik Air Sumur Gali di Perkotaan: JURNAL VISIKES. Vol 11/ no 2
Kementerian Kesehatan Repubik Indonesia, 2010, Peraturan Menteri Kesehatan Republik Indonesia No. 736 Tahun 2010

Mangarey. Frisky Brain, Ricky C Sondakh, Paul A T Kawatu. 2014. Hubungan Antara Konstruksi Sumur Gali Dan Jarak Terhadap Sumber Pencemar Dengan Kualitas Bakteriologis Air Sumur Gali Di Desa Moyongkota Kecamatan Modoyang Barat. Manado: Universitas Sam Ratulangi Fakultas Kesehatan Masyarakat

Marsono.2009. Faktor - Faktor Yang Berhubungan Dengan ualitas Bakteriologis Air Sumur gali Di Pemukiman. Semarang: Program Pascasarjana Universitas Diponegoro Semarang. Thesis

Mugi Rahayu, Tutut, 2015, Studi Kualitas Air Bersih Sumur Gali di Dusun Japun Desa Kewangunan Kecamatan Petanahan Kabupaten Kebumen Tahun 2015. Skripsi. Purwokerto: Kementerian Kesehatan RI Politeknik Kesehatan Semarang Jurusan Kesehatan Lingkungan Purwokerto

Mukono.2000. Prinsip - Prinsip Kesling. Surabaya: Airlangga Universitu Press

Munifah, S. Nurjazuli. Setiani, O. 2003. Kualitas Fisik Dan Kimia Air Sumur Gali dan Sumur Bor Di Wilayah Kerja Puskesmas Guntur II Kabupaten Demak. Demak : Jurnal Kesehatan Lingkungan Indonesia, vol 12, no 2

Notoatmojo, Soekidjo. 2010. Metodelogi Penelitian Kesehatan. Jakarta: Rineka Cipta

Pemerintahan Desa Tambaharjo. 2017. Profil Desa Bulan April 2017

Peni, Adi Anggasiwi.2015. Analisis Limbah laundry Terhadap Kualitas Kimia Air Sumur Gali Di Wilayah Kampus UNNES Semarang 2015. Tugas Akhir. Semarang:Universitas Dian Nuswantoro Fakultas Kesehatan

Peraturan Pemerintah RI Nomor 20 Tahun 1990 tentang Pengendalian Pencemaran Air

Pujiati, R.S dan Pebriyanti, D.O. 2010. Pengaruh Sumur Gali Dengan Septictank Terhadap Kandungan Bakteri Coliform Pada Air 
Sumur Gali.Lumajang : Jurnal IKESMA.vol 6 no 1

Polimengo.Yuliana.2014. Uji Kandungan Bakteriologi Pada Sumur Gali Ditinjau Dari Konstruksi Sumur Di Desa Sukamakmur Kecamatan Patilangi Kabupaten Pohokuato Tahun 2014.Gorontalo:Universitas Negeri Gorontalo

Santjaka Aris.2011. Statistik Untuk Penelitian Keehatan 1. Yogyakarta: Muha Medika

Sanropie, Djasio, dkk. 1998. Penyediaan Air Bersih Akademi Penilik Teknologi Sanitasi (APK - TS). Jakarta: Pusat Pendidikan Dan Latihan Pegawai Departemen Kesehatan RI

Sastroasmoro, Sudigdo. 2011. Dasar - Dasar Metedologi Penelitian Klinis Edisi 4. Jakarta: Sagung Seto

Sosongko, E.B, Widiastuti, E. Priyono, R.E. 2014. Kajian Kualitas Air Dan Penggunaan Sumur Gali Oleh Masyarakat Di Sekitar Sungai Kaliyasa Kabupaten Cilacap. Semarang: Jurnal Ilmu Lingkungan.vol 12 isuee 2 : $72-82$

Standar Nasional Indonesia No 06-6989.1-2015 tentang Cara Uji Kadar Sulfaktan amoniak sengan spektofotometer secaa biru metilen
Totok Sutrisno, dkk. 2006. Teknologi Penyediaan Air Bersih. Jakarta: PT Rienka Cipta

Tri Cahyono, 2014, Pedoman Penulisan Proposal Penelitian Dan Karya TulisI Imiah /SkripsI Edisi Revisi Ketiga, Purwokerto: Kementerian Kesehatan Republik Indonesia Politeknik Kesehatan Kemenkes Semarang Jurusan Kesehatan Lingkungan Purwokerto

Ulfatuzzahroh. 2010. Hubungan Antara Konstruksi Dengan kandungan Bakteri Colifrom Air Dumur Gali Di Desa Pangebatan Kecamatan Karanglewas Kabupaten Banyumas Tahun 2016. Purwokerto: Kementerian Kesehatan RI Politeknik Kesehatan Semarang Jurusan Kesehatan Lingkungan Purwokerto

Undang - Undang Republik Indonesia No. 7 Tahun 2004 Tentang Sumber Daya Air

Undang - Undang Repulik Indonesia Nomor 36 Tahun 2009 Tentang Kesehatan 